\title{
From Fighting Formal Wars to Maintaining Civil Peace? PHILIPPE DROZ-VINCENT
}

Department of Political Science, University of Toulouse 14, Toulouse, France; e-mail: idroz.vincent@wanadoo.fr

doi:10.1017/S0020743811000535

In the 2011 wave of popular uprisings shaking authoritarian rule in the Middle East, mass societal mobilizations have been the crucial factor. But institutional actors, especially armies, are also playing an active role. Armies in the region have generally had less and less involvement in formal interstate wars and consequently have played more of a role, willingly or not, in underpinning regimes. Recent events demonstrate two patterns: armies that have refused to play this role (Egypt, Tunisia) and armies that have been willing, at least for some time, to answer the regimes' requests to engage in repression (Bahrain, Yemen, Syria) or even civil war (Libya). How can we account for the military's growing role in civil strife or civil peace?

To assess the stance of armies when facing massive popular mobilizations, we need to understand what role they perform under enduring authoritarian regimes. The preparation for and conduct of formal, interstate wars, such as those between Israel and Arab states, help to explain the numerous advances armies made into politics in the 1950s and 1960s. ${ }^{1}$ Regimes emerging from the military coups d'état of these decades gained some legitimacy or at least preserved their political hegemony throughout the second half of the 20th century and into the 21st, as exemplified in Egypt by the status of the

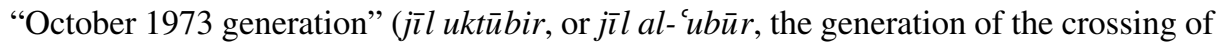
the Suez Canal that signaled the beginning of the 1973 war). Little wonder that Husni Mubarak, in his desperate plea on state-controlled TV on 1 February 2011, ten days before stepping down, alluded to his personal role fighting for the sake of his country in 1973.

That era is over. The influence of the military qua military has receded as Arab states have become huge structures, much more complex than the thin (civilian) states that came out of the independence era. Social structures have undergone considerable change since the time when the military could seize power by issuing a "Communiqué No. 1" in the capital and promising a new national project.

With the parallel waning of formal wars and coups d'état after the $1970 \mathrm{~s},{ }^{2}$ the military became an essential part of the institutionalization of authoritarian regimes. But these were not military regimes per se, even though authoritarian rulers had the ultimate backing of the army, the primary purveyor of lethal force. In fact, a fine but essential line was being drawn between the military as integrated within the political regime (with some officers playing crucial roles in the corridors of power) and the military as an institutional part of the state (the military as a corps keeping some distance from day-today politics). Even in countries such as Egypt, Syria, Iraq, Libya, and Yemen-where officers headed up new republican regimes or presidents hailed from the military but wore the civilian suit-there has been a creeping "civilianization" or "demilitarization" of the regime. ${ }^{3}$ This trend was accentuated through decades of authoritarian rule that concentrated executive power in a few networks of family members, high officials from the bureaucracy, politicians, economic cronies, and officers linked to the president/king 
(rather than representing the army as a corps). ${ }^{4}$ Among the high officers' corps, authoritarianism has a propensity to produce its own creatures, who are characterized by a mix of unwavering loyalty, caution, and resistance to change. They are also able to keep the military loyal to the regime and prevent the armed forces from building a sense of national mission as occurred in the 1950s and 1960s. Arab regimes have aimed at the progressive institutionalization of the military apparatus into the authoritarian state, which has entailed a mixture of professionalism and corporate identity with enduring cronyism, patrimonialism, and preferential treatment of high officers close to regimes. ${ }^{5}$

Some regimes have been more interventionist in their armies than others. In Yemen, Syria, Libya, Bahrain, and Saudi Arabia, regimes have drawn the army close through various kinds of interrelations. The army has been characterized in Yemen by the deep penetration of tribal relations and the rise of senior commanders from the North after the reunification war of 1994, in Syria by the 'Alawi community's preferential recruitment into top military posts, in Libya by family and tribal networks, in Bahrain by a Sunni bias, and in Saudi Arabia by familial allegiances. Some armies are counterbalanced with strong dual militaries (such as the National Guard in Saudi Arabia) or special forces and praetorian forces (such as those in Syria and Yemen, which in the latter case were built with U.S. assistance under the guise of counterterrorism). Colonel alQadhafi has even destroyed the regular army as a corps. In the Gulf monarchies, armies have been systematically "underdeveloped," that is, undersized in comparison to the scale of potential threats, both because too strong an army could represent a threat and because regimes could rely in an emergency on "over the horizon" protection from the United States, whose 5th Fleet is headquartered in Bahrain. In the little Gulf shaykhdoms, security has also been outsourced to foreign (e.g., Pakistani or Jordanian) units, embedded in the national military according to rotation agreements.

This very "special" relationship between militaries and regimes has been an essential feature of enduring authoritarianism, one that is much more complex than the catchphrase: "authoritarianism is backed by military power." Regimes have underpinned the relationship by servicing the military: attending to its corporate interests (large budgets, modernization programs, freedom from external oversight) as well as to the private interests of its senior officers. In such authoritarian settings - in which the close monitoring and rapid rotations or promotions of officers are also employed - the military preserves a "quietist" stance not unlike that adopted by many religious elites toward the state. The army has positioned itself as a symbol of the state, carefully cultivating the image of an actor at the service of the country (in Egypt, Jordan, Tunisia, and in some sense Saudi Arabia) while generally abstaining from the dirty task of policing society. As a result, it has been able to retain some legitimacy without threatening the regime.

In general, the army in authoritarian Arab states was able to balance the comforts of "quietism" and the preservation of its corporate interests with the need to respond to regime requests to reestablish order when internal security forces lost control. But the military was never enthusiastic about this latter role, except in Algeria, where it waged a fierce civil war in the 1990s (and even there it formed village and communal guards to bear a significant part of the burden). Nor has the military cut itself off completely from societal trends and changes. In recent years, retired officers with links to officers in active service have become increasingly vocal about their political concerns: in Egypt 
they circulated open letters in elite circles about Mubarak's succession in August 2010; in Jordan such officers used the internet to openly question the "ethnic" identity of the kingdom in April 2010.

This helps explain why, in 2011, the army was the only institutional actor able to survive the collapse of the Egyptian and Tunisian regimes intact: the secret police, anti-riot forces, and other agencies of coercion retreated in the face of mass social mobilization, while other institutions and extensions of the dominant political parties were completely delegitimized. The army protected ministries and public buildings and thereby played the role of midwife for political transitions in Tunisia and Egypt. In both countries, the refusal of the army to shoot at protesters-which would have tarnished its own image and threatened its own cohesion-sealed the regime's fate. But in Egypt, where the army is much more exposed (in the Supreme Council of the Armed Forces) than in Tunisia (where it quickly went "back to the barracks"), transition might also take place within the army. New generations of officers have been shaped by new processes of socialization, which have opened the military to external influences quite different from those associated with the image of the military as a closed, corporatist force. While the same holds true for Jordan and maybe Saudi Arabia, it is especially the case in Egypt, where U.S.-sponsored training programs have taken officers abroad and exposed them to new conceptions of the military as a professional corps. These officers may weigh in while continuing to value the maintenance of the military's cohesion.

In cases where the relations between regimes and armies are characterized by duality (Libya), bias (Bahrain), or praetorianism (Syria and Yemen), the army is more willing to be assigned a role in maintaining internal order on behalf of the incumbent regime. The army has been involved in repression in Bahrain, as have the internal security forces and Saudi adjunct forces. The same has held true for Yemen, though the Yemeni army has begun to fracture. In Libya, the army imploded in the first "days of anger," but the regime has since used parts of it to reinstate a coercive apparatus. The Libyan military has been complemented by adjunct forces recruited in a war-torn region: the so-called Libyansponsored Islamic Legion that engaged in Chad in the 1980s and then reappeared as armed groups in various other regional conflicts (some were the Janjawid in Darfur), before being recalled by the al-Qadhafi regime in 2011 for repressive tasks. But the prospect of armies having to confront massive, nonideological, nonsectoral, and peaceful popular mobilizations with heavy lethal power could fracture the officers' corps, displaying the high stakes of the military's growing role in civil strife or civil peace in 2011.

\section{NOTES}

\footnotetext{
${ }^{1}$ Steven Heydemann, War, Institutions, and Social Change in the Middle East (Berkeley, Calif.: California University Press, 2000).

${ }^{2}$ Eliezer Be'eri, "The Waning of the Military in Coup Politics," Middle Eastern Studies 18 (1982): 69-81.

${ }^{3}$ Mark N. Cooper, "The Demilitarization of the Egyptian Cabinet," International Journal of Middle East Studies 14 (1982): 203-25.

${ }^{4}$ Algeria is an exception with the enduring encroachment of the état-major of the Armée de Libération Nationale in politics.

${ }^{5}$ Philippe Droz-Vincent, “Quel avenir pour I'autoritarisme dans le monde arabe?" Revue Française de Science Politique 54 (2004): 945-79; and idem, "From Political to Economic Actors: The Changing Role of Middle Eastern Armies," in Debating Authoritarianism in the Arab World, ed. Oliver Schlumberger (Stanford, Calif.: Stanford University Press, 2007).
} 